\title{
The effect of economic downturns on apprenticeships and initial workplace training: a review of the evidence ${ }^{\dagger}$
}

\author{
Giorgio Brunello ${ }^{a, *}$ \\ ${ }^{a}$ University of Padova, CESifo and IZA
}

\begin{abstract}
The existing empirical evidence on the relationship between apprenticeships, initial workplace training and economic downturns, is relatively scarce. The bottom line of this literature is that ratio of apprentices to employees tends to be (mildly) pro-cyclical and to decline during a recession, with the notable exception of the Great Depression, when it rose (at least in England). When broader measures of training are considered, which exclude apprentices, the weight of the evidence is in favour of counter-cyclical training incidence. This paper suggests that a possible reconciliation of these findings is based on recognizing that firms may have incentives to train incumbents during a downturn and at the same time to reduce the recruitment and training of young employees, who are engaged in the transition from school to work.
\end{abstract}

Keywords: apprenticeship training, economic downturns

\section{Introduction}

The world economy is experiencing a severe economic downturn. GDP growth is slowing down sharply and is expected to be negative in 2009 in the US, Japan, Britain and the Euro area. Unemployment is rising and consumer demand is falling, as the real economy is hit by the consequences of the financial turmoil.

Recessions are times of "cleaning up", when outdated or unprofitable techniques and products are dismissed and new technology is adopted (Caballero \& Hammour, 1994). During recessions, the flows out of employment increase and the flows into employment fall. The intensity of these flows vary with age: in the US, young workers experience the highest increase in outflows and the highest decline in inflows. Old workers are less likely to exit but experience a substantial decline in employment inflows (Blanchard \& Diamond, 1990). Therefore, it is especially the young and the

\footnotetext{
${ }^{\dagger}$ Paper prepared for the Education and Training Policy Division, OECD, Paris as part of Learning for Jobs: OECD Reviews of Vocational Education and Training (http://www.oecd.org/document/42/0,3343,en_2649_39263238_40344106_1_1_1_1,00.html)

*Address for correspondence: giorgio.brunello@unipd.it. I am grateful to Kenn Ariga, Andrea Bassanini, Maria De Paola, Simon Fields, Malgorzata Kuczera, George Psacharopoulos, Paul Ryan, Jürg Schweri, Catherine Sofer, Thomas Zwick and Stefan Wolter for help and suggestions. The usual disclaimer applies.
} 
old who are negatively affected by a recession. In many European countries and in Japan, where employment protection legislation and practices shelter permanent employees from redundancies, the brunt of employment adjustment in the recession falls on reducing recruitment, especially of the young (Gielen \& Van Ours, 2005) ${ }^{1}$.

What is the expected effect of the economic downturn on the provision of human capital within firms? There is no quick answer to this question. On the one hand, the cleansing role of recessions calls for additional investment in organizational capital, inclusive of training. On the other hand, we know that training incidence is highest among young employees (see for instance Bassanini et al., 2007): since employment is reduced, at least initially, by cutting on the recruitment of young workers, average training incidence can fall in a downturn as the result of a shift in the composition of employment towards older and more protected workers.

In answering this question, it is also important to distinguish between shallow and severe downturns, and between short training programs, which last a week or a month, and long programs, including apprenticeships, which could last for years. I expect that short recessions will affect short programs more than long programs, because the expected benefits of the latter will accrue mainly when the economy has already recovered. On the other hand, deep recessions as well as prolonged slumps, similar to the one experienced by Japan in the 1990s, may have broader and lasting effects on training.

During recessions, time spent at work becomes relatively less valuable with respect to time spent at school or in workplace training. Individuals and firms shift their efforts from production to retooling their skills and updating their organizational capital. Enrolment in schools increases and training intensity, both in the classroom and on the job, rises. With complete and perfect markets, this reallocation needs not require government intervention: students can borrow more to support higher tuition fees, schools can offer additional slots and firms can find the resources to fund additional training. Furthermore, wages are sufficiently flexible to encourage the recruitment of apprentices. In practice, markets are far from perfect, and government intervention, both in education and in training, is common. Do government policies work? What policies should be adopted to foster the human capital of the young? These are difficult questions, but luckily the economics literature provides some tentative answers.

The purpose of this review is to examine the existing empirical evidence on the relationship between economic downturns and the provision of workplace training to young individuals. This training includes mainly apprenticeships but also short programs - such as internships and traineeships. As defined by Ryan (2000, p. 44) apprenticeships are "...a formal, structured programme of vocational preparation, sponsored by an employer, that juxtaposes part - time off the job instruction with on the job training and work experience, leads to a recognized vocational qualification at craft or higher levels, and takes at least two years to complete. In continental Europe, vocational and general education form part of the package and apprenticeship is

\footnotetext{
${ }^{1}$ See also The Economist, You Are Hired - Next Year, May 2 2009, pp.60-61
} 
treated as part of vocational education, usually at upper secondary level".

In most countries where apprenticeships exist, they tend to concentrate in manufacturing and construction. They are typically accompanied by a set of institutional arrangements that try to resolve some of the problems associated with the scheme, including low educational content, free riding, and under-training, and by government intervention, both as a regulator and (often but not always) as a generous supplier of subsidies. Table 1 at the end of this paper illustrates in a compact way some key features of apprenticeships ${ }^{2}$. It is widely recognized that these institutions work rather well in the countries of Continental and Nordic Europe, but are somewhat less effective in Anglo - Saxon countries ${ }^{3}$.

The review is organized as follows: in the first Section I briefly look at the economic theory; the empirical literature on apprentices and the business cycle is examined in Section 2. Section 3 considers other types of training, including schooling. Section 4 is devoted to policy implications. In Section 5 I ask what data are available to pursue further research in the area. Conclusions follow.

\section{Apprenticeships and the business cycle: the theoretical arguments}

A good starting point in discussing how economic downturns can affect apprenticeships and short - term workplace training episodes is the investment model by Stevens (1994). This is an investment model because it views the demand for apprenticeship as an investment for future production, in contrast with models which emphasize instead the opportunity of substituting more expensive skilled labour with less expensive apprenticeships for the purpose of current production (see Lindley, 1975).

Firms in Stevens' model need to choose between two alternative modes of filling future skilled vacancies: hire skilled labour when the future need arises or train unskilled young labour now in the expectation that it will be ready for future production. This choice is affected by relative costs and benefits. If trained apprentices and skilled labour are perfect substitutes, expected benefits are the same. Costs, however, differ: they are training costs for apprentices and recruitment costs for skilled labour.

Training costs include the wage paid to apprentices - net of their contribution to output during training - and the costs of training facilities, materials and trainers ${ }^{4}$. Compared to training costs, the costs of recruiting skilled labour are only born when recruitment occurs. If skilled labour were abundant and easy to locate and recruit

\footnotetext{
${ }^{2}$ The table was originally produced by Ryan (2000) and extended by Bassanini et al. (2007)

${ }^{3}$ See Harhoff \& Kane (1997) for a discussion of the German apprenticeship system from the perspective of the US labour market

${ }^{4}$ Harhoff and Kane (1997) examine the evidence for Germany and conclude that the training costs born by employers during the apprenticeship period are substantial. In contrast, Mühlemann et al. (2007) show that the majority of Swiss firms manage to recoup their costs before the end of apprenticeships. This difference is related to the higher retention rate after completion of apprenticeships in Germany than in Switzerland, which allows training companies in the former country to recoup their training costs after the end of apprenticeships.
} 
when needed, few firms would train apprentices, unless the burden of the cost of training could be shifted to trained workers or the taxpayer. When future recruitment is costly, however, firms may be willing to offer apprenticeship contracts if by so doing they can produce in-house and at a lower cost the skills required by the time the need arises, and save future recruitment costs (see also Saint Paul, 1993; Brunello $\&$ Medio, 2001; Ryan, 2009; and the references therein).

I extend this model to examine the effects of the business cycle. Suppose that a downturn sets in, with a negative temporary shock to current revenues, and that apprenticeships last for a few periods. Due to the temporary nature of the shock, the future benefits of training are unaffected, and so is the expected cost of recruiting skilled labour in the future. Suppose also that apprentice wages are unchanged. Then the temporary shock has two effects: on the one hand, current productivity declines; on the other hand, if part of the training is carried out by senior workers, their foregone production also declines. The former effect increases training costs and the latter reduces it. If the decline in the apprentice's productivity prevails, training costs increase and the incentive to train now rather than hire in the future falls.

When current output declines but future expected output is unchanged, and there are no costs of adjusting labour, recruitments decline and redundancies of skilled and unskilled labour take place. In this case, although in a downturn the absolute number of apprentices may fall, the ratio of apprentices to employees can increase. When there are substantial costs of adjusting labour, however, current employment may be temporarily hoarded within the firm. Recruitments fall, including those of new apprentices. In this case, the ratio of apprentices to employees can be pro-cyclically.

Compared to apprenticeships, which usually take a few years to complete, training programs of short duration are negatively affected both by the temporary reduction in the current demand for skilled labour and by the decline in the current cost of recruiting skilled labour. Therefore, I expect that, ceteris paribus training courses of short duration are more affected than long courses by temporary shocks.

Next consider a prolonged downturn, which affects both the current and future periods. If the shock extends to the time when apprenticeships are expected to be completed, there are two additional factors at play: first, future recruitment costs fall, and hiring skilled labour from the market when the need arises becomes relatively more convenient; second, the future scale of production is reduced, and so is the need for skilled workers, independently of whether they are trained inside the firms or recruited from outside. Therefore, compared to the case of a temporary shock, a prolonged downturn is more likely to affect negatively training programs which last several periods of time, such as apprenticeships. With a prolonged shock, labour hoarding is a less viable option and redundancies increase. In this case, both the numerator and the denominator of the ratio of apprentices to employees are affected negatively and to a larger extent than in the case of a temporary shock.

An alternative to the investment model of apprenticeships is the substitution model, which states that the relative demand for apprentices depends on output as 
well as on their wages relative to those of skilled employees. Assuming that relative wages are not affected by a temporary downturn, the substitution hypothesis predicts that a temporary reduction of output leads to a reduction in the number of apprentices and skilled labour employed by the firm, with no change in their relative share. When skilled labour is costly to adjust, however, firms may choose to have a core of skilled permanent labour and a periphery of temporary labour - including apprentices - who can be hired in upswings and shed in downturns ${ }^{5}$.

So far, we have considered the decision to recruit apprentices or to offer training courses to new recruits. Yet an economic downturn affects also the training of current employees. Since the value of foregone production declines, recessions are times for reorganization and for the production of organizational capital (Hall, 1991). One facet of reorganization is training: firms temporarily hoard idle employees in a downturn and train them in the expectation that their productivity will be higher when the next expansion returns. When labour hoarding is important, apprenticeship training may fall in a recession even though continuous training - which refers to (adult) employed workers - increases.

Finally consider training episodes initiated by individuals rather than by firms. During recessions individuals re-direct their activities away from production and toward leisure, home production and the production of human capital. By doing so, they take advantage of the lower foregone costs of production. If training requires resources, however, the shift toward training during a downturn could be hampered by the presence of liquidity constraints ${ }^{6}$.

\section{Apprenticeships and the business cycle: the empirical literature}

The existing empirical research on the cyclical pattern of apprenticeships and initial workplace training covers only a few developed countries. Typically, but not always, this evidence is based on econometric estimates that associate initial workplace training to business cycle indicators. The main findings are summarized in Table 2 at the end of the paper. In this section, I review this evidence. In the next section, I consider instead the few empirical studies which have looked at the relationship between a broader definition of training and economic downturns.

In her empirical application of the investment model discussed in the previous section, Stevens (1994) uses data from the British engineering industry covering the period 1967 to 1988 . The recruitment of first - year craft trainees fell considerably in the early 1970s, in the wake of the first oil shock, recovered in the second part of the 1970s and fell sharply again during the 1980-81 recession. Stevens is mainly interested in the association between the ratio of apprentice recruitment to craft employment - in logs - and an index of relative skill shortages, which captures the cost of recruiting skilled labour: the tighter the labour market the higher the $\operatorname{cost}^{7}$.

\footnotetext{
${ }^{5}$ See for instance Boeri and Garibaldi (2007) and the references therein

${ }^{6}$ Dellas and Sakellaris (2003) discuss these issues in the context of college education.

${ }^{7}$ This index is computed as the difference between the CBI (Confederation of British Industry) skill
} 
Her empirical results show that this association is positive. It is not clear, however, whether her results can be taken as supportive of her theory, which suggests that the recruitment costs that matter are not the current ones but those at the time when apprentices are expected to have completed their training.

More interesting for the purposes of this review is the estimated relationship between the business cycle and the ratio of apprentices to employees. A positive relationship would suggest that this ratio is pro-cyclical; a negative relationship would point instead to a counter-cyclical behaviour. In one of the empirical specifications she presents, Stevens shows that the log ratio of apprentices to employees decreases when: a) the CBI capacity shortage index CAPSH increases; b) the CBI index of absolute skills shortages SKSH declines. Both indicators move pro-cyclically and attract similar coefficients. Since the difference between SKSH and CAPSH is procyclical, this evidence suggests that the ratio of apprentices to employees declines during downturns.

In another study using data from the British engineering industry, Hart (2005) examines how the employment of apprentices and skilled journeymen adjusted during the years of the Great Depression. He uses data that cover 27 district associations of the Engineering Employers Federation, 8 occupations and the period 1928 to 1938. He estimates dynamic employment equations for apprentices, crafted journeymen and the ratio of the two, using the current and lagged change in the district unemployment rate as an indicator of business cycle conditions. He finds that: a) the employment of both apprentices and journeymen moved pro-cyclically, but the response of the former was delayed with respect to the latter; b) the ratio of apprentices to journeymen moved counter-cyclically.

According to Hart, the quicker response of the employment of journeymen to worsening labour conditions can be explained by wage rigidity, which made many journeymen unprofitable from the outset of the recession. In the absence of employment protection measures, the sudden decline in output was met initially with the layoff of journeymen and only in a second time with the shedding of (cheaper) apprentices. As suggested by the investment model presented verbally in the previous section, the delayed adjustment in the number of apprentices can be interpreted as the consequence of the fact that the decline in output was initially considered as temporary and became prolonged only later. An alternative explanation based on the substitution hypothesis is favoured by Hart, who argues that firms in the downswing preferred to retain initially experienced apprentices, who were cheaper than the journeymen and could do most of their work.

In a third study of the UK experience, Felstead and Green (1996) examine the impact on training of the recession of the early 1990s, using data from the Labour Force Survey. In their descriptive analysis they report that the total number of apprentices declined from 367,000 in the spring of 1989 to 312,000 in the spring of 1992, a 15 percent decline. The percentage of employees on an apprenticeship scheme was mildly pro-cyclical, hovering around 1.5 percent, not far from the value taken in

shortage index and the CBI capacity shortage index. 
the mid to late $1980 \mathrm{~s}^{8}$. Considering the severity of the recession, the decline in the proportion of employees receiving training was a small one ${ }^{9}$.

In a recent study of apprenticeships in the US construction industry, Bilginsoy (2003) examines how the cancellation and completion rate of apprenticeships vary with the business cycle, measured by the state unemployment rate. In the US, apprenticeships have traditionally played a much smaller role in the training of labour than in Europe, partly because the institutional arrangements required to ensure incentive compatibility - firms don't fail to deliver training and individuals do not quit before the end of the training scheme - have been lacking ${ }^{10}$. Apprenticeship schemes have survived mainly in the construction industry, and last between three to four years. Cancellations occur when the apprentice quits the scheme; completions can vary in duration depending for instance on the availability of training jobs.

Bilginsoy uses the data from the Apprenticeship Information Management System compiled by the Bureau of Apprenticeship Training, which contain information on the apprenticeship start and exit rates and type of exit of more than 10 thousand apprentices over the period 1989 to 1995 . He estimates a competing risk model with two hazards, the cancellation and completion hazard, which measure the probability of leaving the stock of apprentices at a given point in time, and finds that both cancellations and completions moved pro-cyclically, which implies that the stock of ongoing apprentices was higher in a downturn. Cancellations decline in a downturn because apprentices have fewer opportunities of quitting and taking up semi-skilled jobs that pay a higher wage than apprenticeships ${ }^{11}$. Completions also decline as the number of training jobs falls. Bilginsoy's study is interesting because of the emphasis it places on the apprentice's choice, rather in contrast with Stevens' model, where the key decisions are taken by profit maximizing employers ${ }^{12}$.

Evidence that the share of apprentices in total employment is pro-cyclical is presented by Askilden and Nilsen (2005) in their study of the Norwegian labour market. Apprentices in Norway are based on the " $2+2$ " system, with the former two years spent in vocational schools and the remaining years with a firm (see Kuczera et al., 2008). Askilden and Nilsen model the demand for apprentices and adult workers (aged 18 years or above) using a translog cost function. Under the assumption that the cyclical variation of cost shares is dominated by quantities rather than prices, they estimate the association between these shares and the unemployment rate, both

\footnotetext{
${ }^{8}$ See also Greenhalgh and Mavrotas (1993), who investigate the effects of the UK recession in the early 1980 s.

${ }^{9}$ In autumn 1992, Felstead and Green interviewed 157 mostly small and medium-sized employers to understand how their training strategies changed during the $90-92$ recession. They found that $43 \%$ of respondents claimed to have increased their training activities in the last two years, while $27 \%$ reported no change, and $25 \%$ reported cutbacks in training.

${ }^{10}$ See Elbaum (1995).

${ }^{11}$ The poaching threat is likely to fall in a downturn, which encourages the employer's incentive to invest.

${ }^{12}$ Additional evidence on apprenticeship registrations and completions is provided for Canada by Sharpe, Asenault and Laponte (2008). Toner (2003) presents evidence on Australian apprenticeships and show that they declined sharply during the recession of the early 1990s.
} 
current and four quarters ahead, using quarterly data collected by the Norwegian Employers' Federation on the manufacturing and construction industries for the period 1990-1996.

They find that the employment of adult workers increase both with the current and with the forward unemployment rate, which they interpret as evidence that firms employ skilled labour when it is in abundant supply (the unemployment rate is high $)^{13}$. They also find that the number of apprentices is pro-cyclical and decreases with the current and forward unemployment rate. The latter finding is consistent both with the investment model, because a lower forward rate signals higher recruitment costs for skilled labour, and with the substitution model, which implies that apprentices belong to a more flexible peripheral labour force, that increases in booms and falls in downswings. Overall, their results imply that the ratio of apprentices to adult workers is pro-cyclical.

Norwegian students enrolled in vocational tracks need to find a suitable slot in firms to complete their apprenticeships. In an economic downturn, when there are fewer vacancies, completion can take place at school, but is clearly a second best solution (see Kuczera et al., 2008). Because of this, the ratio of apprentices to students enrolled in vocational schools is likely to increase in a boom and fall in a downturn. An admittedly gross way of exploring this aspect further is to express the ratio of apprentices to students enrolled in upper secondary schools as follows

$$
\frac{A}{T}=\frac{A}{V} \frac{V}{T}
$$

where A, T and V denote the stock of apprentices and the stock of students enrolled in upper secondary education and in the vocational track respectively ${ }^{14}$.

I use the data from Statistics Norway to plot in Figure 1 the ratio of apprentices to pupils in secondary education $(\mathrm{A} / \mathrm{T})$ against the national unemployment rate during the period 2001 to 2007: there is a clear negative relationship, with the ratio increasing when the unemployment rate falls. At the same time, the ratio of apprentices to pupils in VET schools (A/V) declines and the percentage of pupils in VET schools $(\mathrm{V} / \mathrm{T})$ increases when the unemployment rate increases (see Figure 1). This suggests that the pattern of the $\mathrm{A} / \mathrm{T}$ ratio is pro-cyclical because the increase in the share of VET students taking up an apprenticeship in an economic upswing more than compensates the decline in the percentage of pupils enrolling in VET tracks.

A candidate reason why the ratio $\mathrm{V} / \mathrm{T}$ increases during an economic downturn is that the percentage of school dropouts who leave vocational schools follow a procyclical pattern: when the economy is expanding, the value of time at work raises relative to time at school and many pupils enrolled in the VET track find opportuni-

\footnotetext{
${ }^{13}$ This finding is puzzling, because employment is typically pro-cyclical; moreover, it is based on the assumption that all adult workers are skilled.

${ }^{14}$ The number of students in upper secondary education and in vocational schools is gross of apprentices. In Norway, as in many other European countries, secondary education includes both vocational and academic tracks.
} 


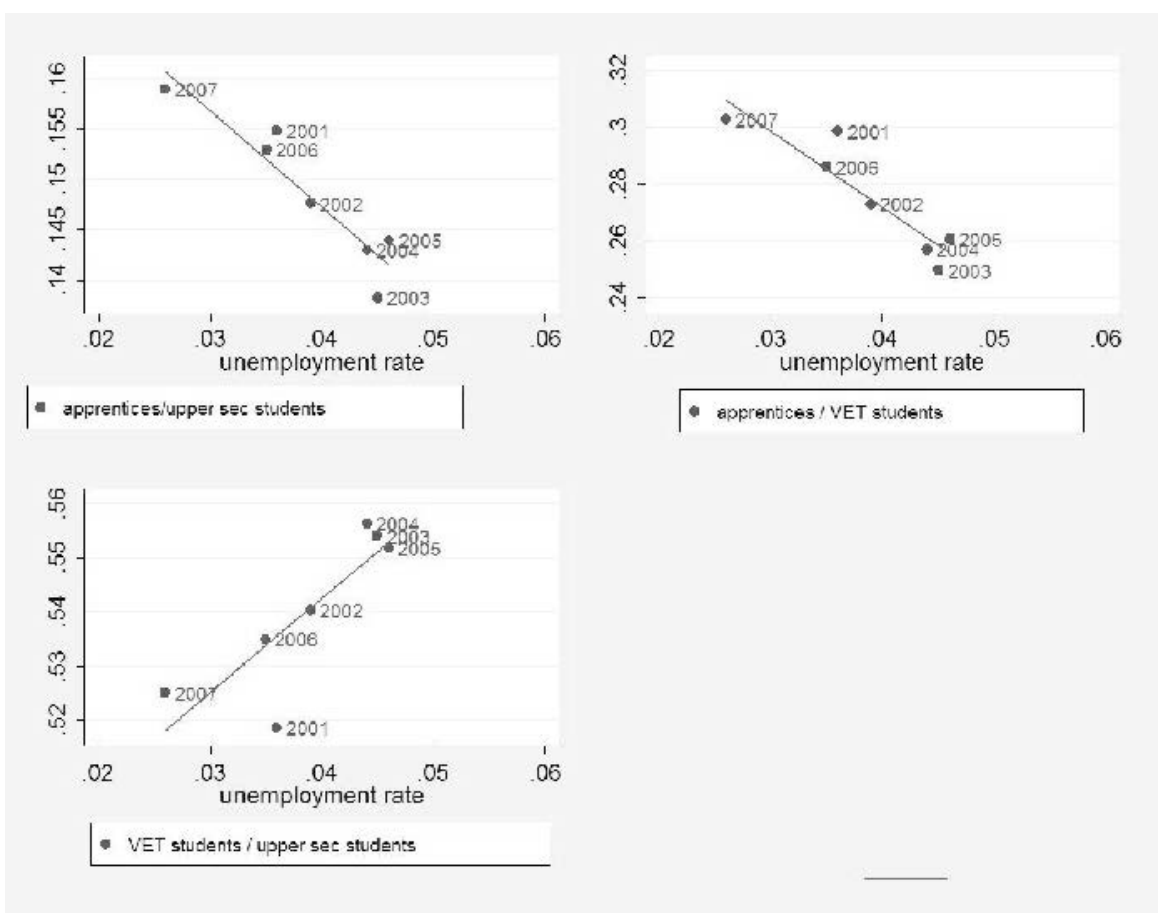

Figure 1: The apprentices / students ratio and unemployment rate in Norway

ties to work in the labour market without going through an apprenticeship ${ }^{15}$. Since in the Norwegian system individuals who started work without completing an apprenticeship are allowed to sit exams for skill certificates after a few years of work experience, dropping out of school in an upturn to take up better paying jobs appears to be a valid alternative to apprenticeships.

The country which has attracted international attention for the quality of its apprenticeship system is Germany, with its dual system of education (see Ryan, 2001; Culpepper, 1999; Harhoff \& Kane, 1997). A similar system is implemented also in Austria and Switzerland. A descriptive study of the effects of the recession of the early 1990s on the German apprenticeship system was carried out by Wagner (1998). She compared the apprentice training ratio (apprentices to employees) in 1990 and 1995 in West Germany and found that this ratio fell from 7 to 5.5 for the entire economy, from 10.9 to 8 among firms with 1 to 9 employees and from 5.2 to 4.3 among firms with at least 500 employees. She also found that the percentage of plants doing apprentice training declined from 28.3 to 23.7 percent during the same period. In

\footnotetext{
${ }^{15}$ The choice of leaving school to take up a job is less open to students enrolled in academic tracks, who are typically college bound.
} 
the absence of a multivariate analysis, however, it is difficult to attribute this decline to the economic downturn, because other factors could matter, including changes in industrial composition and long term trend effects ${ }^{16}$. In contrast, Jaconebbinghaus et al. (2008) show that the percentage of apprentices during the downturn of the early 2000 was quite stable, which they interpret as showing that German business does not show less inclination to train apprentices during bad times.

Schweri and Mueller (2008) use Swiss firm data for the years 1995, 1998, 2001 and 2005 and find that the percentage of training firms is positively correlated to average GDP growth in the past three years. Furthermore, they present a graphical analysis of the correlation between the rate of GDP growth and the share of individuals aged 16 who are involved in an apprenticeship. The share is pro-cyclical, in line with the Norwegian results discussed above ${ }^{17}$. Rasmussen and Westergaard-Nielsen (1999) study instead apprenticeships in Denmark, using data on 720 plants with apprentices during the period 1980 to 1991 . They find that the probability of having a new apprentice is positively associated to the rate of new hires and negatively correlated to the rate of job leavers, which points again to the pro-cyclical behaviour of workplace training.

\section{Training and the business cycle: the empirical literature}

In this section, I briefly review the literature on the relationship between the business cycle, schooling and the accumulation of workplace training, including continuous training. The selected contributions are summarized in Table 3 at the end of the paper. Sepulveda (2004) develops a real business cycle model with employment adjustment costs, labour hoarding and counter-cyclical training activities. In a downturn, the foregone production cost of training declines, labour is retained because of the presence of adjustment costs and training occurs, much in the spirit of Hall's model of organizational capital (Hall, 1991) ${ }^{18}$. Sepulveda uses data from the US National Longitudinal Survey of Youth (NLSY) to construct a panel of individuals aged 14 to 22 in 1979, which he follows until 1998. He focuses on the incidence and intensity of off-the-job and on-the-job training, measured in hours and net of apprenticeships, and reports that they are weakly counter - cyclical, lead the cycle and are highly volatile, with a standard deviation of more than 10 times that of output ${ }^{19}$.

Majmudar (2007) also uses NLSY data for the period 1979 to 1988 but finds that the probability of receiving company training decreases when the local unemployment rate increases, which points to pro - cyclical training. This negative association,

\footnotetext{
${ }^{16}$ Culpepper (1999) argues that the decline in apprentice positions in West Germany since the 1980s is a long-run challenge to the "high - skill equilibrium" prevailing before

${ }^{17}$ In a recent contribution, Mühlemann et al. (2009) use Swiss panel data for the period 1988-2004 and find that the number of new apprenticeship contracts fall when the cantonal unemployment rate increases.

${ }^{18}$ According to the European Foundation for the Improvement of Living and Working Conditions, a common feature of recent measures to reduce the impact of the economic downturn on European employment has been the negotiated reduction of working time balanced by increased provision of training.

${ }^{19}$ The cyclical indicator used by Sepulveda is the deviation of quarterly real GDP from trend.
} 
however, is only statistically significant for workers who have joined the firm since the last wave. Majmudar motivates his results as the outcome of two countervailing effects, with the latter dominating the former: on the one hand, labour market opportunities for trained workers are fewer in a downturn, which reduces their bargaining power with the firm and increases the employer's incentive to train. On the other hand, there are many alternatives to training in a slack labour market, which induce firms to hire rather than train.

Bassanini and Brunello (2008) study the relationship between product market regulation and workplace training, using data for 15 European countries and 8 years drawn from the European Labour Force Survey. They only consider individuals aged 25 to 54, which rules out most apprenticeship episodes. They find that their measure of training incidence - the proportion of employed individuals who received training in the four weeks before the reference week - is negatively correlated to their measure of the business cycle, the logarithm of worked hours filtered from trend with the Hodrick - Prescott filter, in line with Sepulveda's findings for the US.

Dellas and Sakellaris (2003) study the relationship between schooling and the business cycle. Their contribution is interesting for the purposes of this review because it illustrates the key factors at play in the individual decision to invest in human capital, either at school or in a training institution. The key trade-off here is between the opportunity cost of training, which declines in a downturn, and ability to pay, which is typically lower in a recession. In the absence of borrowing constraints, human capital accumulation is counter - cyclical. However, if credit markets are imperfect and individuals are liquidity constrained, investment can turn pro-cyclical ${ }^{20}$. Their empirical evidence on the pattern of college enrolment in the US shows that enrolment is counter - cyclical, which suggests that the opportunity cost argument prevails. Similar evidence is presented by King and Sweetman (2002) who show that school retooling - individuals leaving the labour market to return to school - is pro - cyclical. Notice the qualitative similarity of these results with those obtained by Bilginsoy on apprenticeship training in the US and with our discussion of enrolment in vocational schools in Norway.

An additional reason why young individuals tend to stay on or to enrol in school during a downturn is that entering the labour market in a recession can have persistent effects on employment prospects and earnings. Oreopoulos, von Watcher and Heisz (2009) for instance, show that the initial earnings loss is substantial and fades only after 8 to 10 years after graduation ${ }^{21}$.

In Asia, the Japanese experience is of particular interest. Japan experienced a prolonged slump after the burst of the asset prices bubble at the end of the 1980s. The Japanese unemployment rate increased sharply, especially among the young. Considering the age group 20 to 24 , it rose from 3.7 percent in 1990 to 8.7 percent in 1999 (see Genda \& Rebick, 2001). In spite of the slump, the so called lifetime

\footnotetext{
${ }^{20}$ Liquidity constraints are less likely when students can borrow tuition money. See for instance the The Economist, Desperemus igitur, April 25th 2009, pp.47-48.

${ }^{21}$ See also Kahn (2006) and Baker et al. (1994).
} 
employment system was basically unchallenged, with permanent employees enjoying a high degree of employment protection (see Ariga et al., 2000; Kato, 2000). Its relative share of total employment, however, declined at the expense of an increased periphery of temporary workers, mainly young, who could not find access to the guaranteed core. Extensive dismissals of core employees were by and large avoided, especially during the first part of the 1990s, but the recruitment of new young workers as permanent employees was drastically cut. Because many Japanese (large) firms provide extensive training to their new permanent recruits and hire mainly if not exclusively at well defined ports of entry, one of the effects of the slump was the increase in the average age of permanent employees. Since training intensity declines with age, an additional likely effect was the reduction in average training incidence and intensity. This reduction could not be compensated by the increased recruitment of temporary employees, because these workers typically receive less training (see Genda \& Kurosawa, 2001 and Ariga, 2006).

Notice the contrast between the Japanese experience during the slump of the 1990s and the British experience during the Great Depression described by Hart (2005) and reviewed above. In the latter case, lack of employment protection meant that firms in the engineering industry reduced first the number of skilled journeymen and only in a second time the number of apprentices. In the former case, the presence of substantial costs of adjusting permanent labour led to a drastic reduction in the recruitment of the young in permanent jobs and to the expansion of a periphery of temporary labour, who received less training. Because to the duration of the Japanese slump, many young school graduates, who were unlucky enough to enter the labour market in the early 1990s, ended up trapped in a sequence of temporary jobs, more or less losing their chance to find their way into the core of permanent employment when the economy eventually recovered. The economic cost in terms of foregone opportunities to accumulate human capital has not been estimated but could have been substantial ${ }^{22}$.

The observation that prolonged recessions could trigger the expansion of temporary contracts is not only based on the Japanese experience. In an investigation of the Swedish slump of the early 1990s, Holmlund and Storrie (2001) argue that that recession induced an initial decline in temporary employment, followed by a sharp rise from the through to its end. Fixed - terms contracts were only 10 percent of total employment in Sweden in 1990 but rose to 16 percent at the end of the decade. A similar - and even sharper - experience was shared by Finland. Since temporary workers are known to receive less training, one of the potential side effects of a prolonged slump is the permanent reduction in average training intensity associated to a shrinking core of permanent employees and to an increased share of temporary labour.

\footnotetext{
${ }^{22}$ Genda (2005) is a vivid description of the phenomenon of "freeta" workers, who are trapped in a sequence of temporary jobs.
} 


\section{Policies}

In many countries public intervention that focuses on apprenticeships is not limited to designing formal rules, but also includes financial support. These policies are often justified with the argument that in the absence of public intervention the market produces less than the optimal share of apprentices ${ }^{23}$.

In the apprenticeship systems prevailing in Germany, Denmark, Austria and the Netherlands the state pays for formal education while the firms and apprentices pay for the training on-the-job. In some case, the state also offers additional subsidies, as in the case of Denmark. The role of firms as financing subjects is very important in these countries. In France firms pay an apprenticeship tax that dates back to 1925 and is mainly used by enterprises to finance - together with the state, local communities and professional organizations - the cost of apprentice training in the Apprenticeship Training Centres. In other countries, for example Italy, the public contribution is considerable and firms which offer these contracts are exempted from paying nearly $100 \%$ of payroll taxes. On the other hand, training content and quality is subject to low monitoring (Croce, 2005).

Training policies are an important component of active labour market policies (ALMP) in OECD countries. The OECD has developed a database on public training expenditures covering the period between 1985 and 2006. Labour market training within ALMP is divided into two categories: a) spending on vocational and remedial training for unemployed adults; and b) training employed adults for labour market reasons. Furthermore, youth measures include training and employment programmes targeted at the young unemployed and apprenticeship training for school leavers (Martin \& Grubb, 2001). Public training expenditure as a percentage of GDP in 2006 ranged from below 0.1 percent in Japan and the Anglo-Saxon countries to above 0.3 in Germany, Sweden and Finland. If I regress this expenditure on country dummies and the first lag of the rate of growth of real GDP per capita, I obtain that a one percent reduction in GDP growth is associated to a 3.84 percent increase in training expenditure. Therefore, public outlays to encourage training increase when GDP growth declines.

Do these policies work? When evaluating the effects of training policies on individual earnings and employment prospects, one needs to consider both deadweight losses and substitution effects. These policies might fail to substantially increase the number of skilled employees, either because part of the financial support goes to investments that would have been realized anyway, or because firms may substitute workers who are not affected with the recipients of training policies. In the case of deadweight losses, both the efficiency and the equity arguments usually employed to back up policies are undermined, since the final beneficiary of the subsidy is not the worker, but the employer, who would have delivered the training even without the public policy. Substitution effects may be particularly relevant in an economic

\footnotetext{
${ }^{23}$ As discussed in some detail by Bassanini et al. (2007) the empirical evidence supporting the underinvestment hypothesis is far from convincing.
} 
downturn, because additional subsidies paid out to firms to hire apprentices may reduce employment opportunities for unskilled and semi-skilled labour not targeted by the policy.

In a recent evaluation of a tax relief policy used in The Netherlands to encourage firms to invest in the training of workers aged 40 years or older, Leuven and Oosterbeek (2004) find no evidence of additional training, but substitution across ages. While this study does not explicitly consider apprenticeships, it suggests that substitution effects across different groups of employees are important. In a study of Switzerland, Muellemann et al. (2009), argue that unnecessary deadweight losses can be avoided is subsidies could only be targeted to non - training firms. In this case, the economic cost would be rather modest. If, however, the exclusion of training firms is not feasible, the public cost of creating additional training positions would be very high.

There is a large literature which evaluates the effects of labour market programmes, including training. Heckman et al. (1999) review this literature and conclude that training policies have limited impact, with partial exception for European countries, where the effects on the probability of employment appear to be more favourable. Martin and Grubb, 2001, also examine this literature and conclude that the evaluation of public training programmes in the OECD suggests a mixed track record: some programmes work, mainly for adult women ${ }^{24}$, but other programmes don't work, especially for disadvantaged youth. In most cases the estimated gain involves employment opportunities. Card et al. (2009) produce a meta analysis of existing studies and conclude that on the job and classroom training programmes are not favourable in the short run (1 year) but have a relatively better impact after two years $^{25}$. Short run effects could even be negative because of the presence of lock-in effects: program participants reduce their search intensity relative to non participants during training.

Lechner and Wunsch (2006) ask whether training policies are more effective in a downturn, when they can be argued to be needed most. Using German data that track different policies for close to ten years, they find that the negative lock-in effects are smaller and the positive long-run effects are larger in times of high unemployment.

In the current recession, policy proposals to combat the current recession emphasize additional investment in education and training. President Obama's 2010 budget plan submitted to the US Congress, for instance, includes significant increases in education funding. The German recovery plan for 2009 devotes 6.5 millions Euros for investment in infrastructure of schools and universities. The OECD (2009) sug-

\footnotetext{
${ }^{24}$ On a similar line, Kluve (2006) argues that treatment effect estimates are negative in a few cases, and often insignificant or modestly positive. Still - he writes - there are several indicators that training programmes do increase participants' post-treatment employment probability, in particular for participants with better labour market prospects and for women.

${ }^{25} \mathrm{An}$ interesting example in the current context is the labour market training policy implemented by local authorities in Finland during the sharp downturn of the early 1990s. Natti et al. (2000) evaluate this policy and finds that it had positive employment effects during the three years following its implementation.
} 
gests that growth-enhancing structural policies can be useful also to promote short term growth ${ }^{26}$. Two such policies are infrastructure projects that improve the quality of existing infrastructure, particularly in education, and increasing expenditure on active labour market policies to "... provide workers with the skills that will be needed as the economy recovers, including through the use of compulsory training programmes" (OECD, 2009, p.19).

In the light or the mixed results reviewed above, the design of training policies seems to be particularly important to enhance their effectiveness. Martin and Grubb (2001) propose that the following four criteria should be met: 1) tight targeting on participants; 2) programmes should be kept relatively small in scale; 3 ) they should result in a qualification or certificate that is recognized and valued by the market; 4) programmes should have a strong on the job component in the programme, and therefore establish strong links with local employers.

In some countries, including Denmark, Germany and Norway, the government tries to compensate for the decline in the number of apprentice positions - for instance due to an economic downturn - by allowing pupils to complete their apprenticeship in a vocational school. Is this a sensible policy? Given the high persistent costs of entering the labour market during a recession without having completed upper secondary education, I am inclined to give a positive answer. Is this policy more effective than paying subsidies to employers who offer additional apprenticeships? Rasmussen and Westergaard-Nielsen (1999) estimate the impact of the Danish subsidy paid out to firms who take up apprentices. This subsidy was introduced in the late 1970s, reduced in size in 1986 and finally discontinued in the 1990s. They use a longitudinal panel of Danish firms spanning the years 1980 to 1991 and find that the subsidy has had an impact on the supply of apprentice positions only in some industries. They estimate that in the affected industries the demand for apprentices would have been $7 \%$ smaller in the absence of the subsidy. They also estimate that the cost to the public purse of a newly created apprenticeship is high, but still considerably lower than the estimated cost of having pupils spend an additional year in vocational schools. They conclude that paying subsidies is more cost effective that offering public places in schools. One problem with subsidies is cream skimming by private employers and the possibility that the less talented and motivated youngsters - who cannot complete their education - are excluded. Another problem is that the presence of generous subsidies may induce firms to use apprentices to fill in unskilled or semi-skilled positions, where little training is involved.

A lesson one can draw from the Danish study is that governments already pressed with alternative uses of resources in a downturn may turn to additional subsidies if this helps reducing the number of pupils who complete their courses in vocational schools. Unless the training activity of firms is adequately monitored, however, results may be disappointing and the consequences of substitution effects may add to the public burden in terms of higher unemployment insurance and social assistance.

Policy intervention that encourages training - both on the job and off the job - is

\footnotetext{
${ }^{26}$ See also the article by Holzer (2009).
} 
perhaps more urgent in a prolonged than in temporary downturn, because of the risk that the young who are hit by the recession are precluded from finding a permanent job, which provides adequate training opportunities. The Japanese experience of the 1990s suggests that the risk of being trapped in a sequence of temporary jobs with little training is serious, with permanent consequences on individual human capital and wellbeing. At least in part, this risk is closely intertwined with the presence of generous employment protection for the core of senior permanent employees. Bassanini et al. (2007) in their study of training in Europe find that average training incidence is negatively affected both by the diffusion of temporary contracts and by the presence of employment protection for regular workers.

The current downturn is accompanied by a sharp reduction in trade flows and by emerging risks of protectionist policies. Policies that limit competition in the product market could damage training. Bassanini and Brunello (2008) estimate the effects of product market deregulation and increased competition in Europe on training incidence and conclude that the estimated effects are significant: depending on the selected measure of regulation and on the empirical specification, a 10 percent increase of regulation reduces training incidence in the exposed industries by 2.8 to 5 percent. The lesson one can draw from this is that training policies are not necessarily the only and perhaps not the best tool available to support training in a prolonged downturn: structural policies that favour product market competition and labour market policies that reduce the dualism between protected insiders and unprotected outsiders may deliver better payoffs than subsidies to workers and employers, which are plagued by the presence of deadweight and substitution effects.

\section{Potential empirical research in the area}

In Europe, international harmonized surveys that cover several countries and have information on training include the European Labour Force Survey (ELFS), the European Community Household Panel (ECHP) and the European Labour Costs Survey (ELCS). The first and the third are repeated cross sections, the second is a panel; the former two are household surveys and the latter is an employer survey.

The European Labour Force Survey contains information on training and individual characteristics such as age, gender, education, labour market status, part time / full time employment, occupation, industry. There are 23 countries in the waves covering the period from 1992 to 2002. Additional countries have been added afterwards, mainly from Eastern Europe, and the definition of many key variables has been changed, making it difficult to use these data until the late 2000s. The survey asks individuals whether they have been in education or training during the four weeks before the interview. This relatively short period of recall reduces the risk of recollection errors at the price of omitting training spells which have ended before the period of reference.

For those who give an affirmative answer, additional questions on the duration and type of training are asked. In particular, there is a question which potentially 
allows one to distinguish between initial education or training and continuous vocational training. Unfortunately, this question has been re-framed in 1998, which reduces comparability over time. Moreover, there are many missing values (especially in Italy, the Netherlands and Portugal). On top of this, the question does not allow to distinguish between education and training, which is especially problematic for the very young who are not employed. The 11 years covering the period 19922002 include both the end of the recession of the early 1990s and the downturn of the early 2000s. If we proxy the phase of the business cycle with the unemployment rate, additional variation can be obtained by focusing on the region of residence, and by comparing regions with high and low unemployment. In spite of its limits, these data can be used to study how training incidence in the young age group vary with economic conditions in a relatively broad group of countries and to investigate what role different institutions can play in changing the shape of the relationship between training and the cycle.

The European Community Household Panel is a household longitudinal survey which includes labour market information on European individuals aged 16 or older. Individuals participating to the survey are asked whether they have been in education or training since January of the year before the interview. Those who give an affirmative answer are then asked to indicate the type of the vocational education course, and the list of available answers include: third level qualification, such as technical college; specific vocational training at a vocational school or college; specific vocational training within a system providing both work experience and a complementary instruction elsewhere; specific vocational training in a working environment. Unfortunately, the number of missing observations is relevant for countries such as the United Kingdom, Austria, Finland and Sweden. Additional questions are also asked on the duration of the relevant course (typically the last). A problem with these data is that they cover the years 1994 to 2001, a period of almost continuous economic expansion. As in the case of the survey ELFS, one can try to exploit the cross-regional variation in economic conditions, see Majumdar, 2007, for the United States.

The European Labour Costs Survey is an employer survey that has been carried out every four years from 1984 to 2004, and covers the core of the European Union plus some Nordic and Eastern European countries. Its renewed version will be on a quarterly basis. These data have information on the number of apprentices and trainees by industry and firm size. Starting with the 2004 wave, they also include information on training costs, which consist of the wages and salaries of trainees and apprentices. Assuming that the survey is carried out regularly in the future, it will be useful to investigate how training costs have been affected by the current recession.

National labour force surveys have the type of information already described in the case of the survey ELFS. The US Current Population Survey, for instance, includes a relevant question on training ("At any time last year, did you attend a training program to learn specific job skills, such as computer word processing, auto mechanics, nursing, providing child care, or a skill for some other job or vocation?"). Household surveys with a longitudinal structure contain information on education 
and training over a relatively long period of time. Given the length of time covered and the wealth of information, these data can be particularly useful to study how economic downturns affect initial training targeted at young individuals. Examples include the German SOEP (Socio-Economic Panel) and the British BHPS (British Household Panel Survey). The former covers the period 1984 to 2006 for West Germany, and 1992 to 2006 for unified Germany. The latter runs yearly from 1993. These datasets have information on current education and training, labour market status, occupation and earnings. The German panel, for instance, asks interviewed individuals aged 16 or older who belong to the selected panel of households whether they are currently in some sort of education, and if yes, investigates the type of education, including apprenticeships. To my knowledge, both datasets have not been used so far to investigate the relationship between training and economic downturns.

\section{Concluding remarks}

The existing empirical evidence on the relationship between apprenticeships, initial workplace training and economic downturns, is relatively scarce and limited mainly to Anglo - Saxon and Nordic countries. We know relatively little about the countries of continental Europe, where the apprenticeship system is widespread and widely admired (Germany, Austria, Switzerland). There is also need to cover other countries, especially those in Southern Europe and Asia. We have limited information on how training costs - mainly apprentice wages - react to economic slumps, and on whether the relationship between initial workplace training and the cycle varies by sector and with firm size and is affected by labour and product market institutions.

In spite of the paucity of empirical research, there is a broad perception that the provision of training is negatively affected by a recession. If one looks at the total number of trainees or apprentices, this could be simply due to the fact that employment falls in an economic downswing. If one focuses instead on the percentage of employees who receive training, the empirical evidence discussed above does not provide a clear picture. Most of the reviewed studies that consider apprenticeships suggest that the ratio of apprentices to employees is pro-cyclical and declines during a recession. The few studies that focus on broader measures of training and exclude apprentices, however, point to a counter-cyclical behaviour, with training incidence that increases during a downturn.

One way to reconcile the existing evidence is to distinguish between young labour market entrants and incumbent employees. Since the latter have accumulated valuable firm specific human capital, firms are often reluctant to lose their skills because of a temporary downturn and tend to engage in some form of labour hoarding, which includes the provision of training. Because of this, the training of incumbents could increase in a downturn. At the same time, firms also reduce recruitments of new employees, and thereby offer fewer apprenticeships. Hence, young labour market entrants in a downturn are more likely to be unemployed or to end up in temporary jobs, which offer limited training. For this age group, training falls. 
The retention of incumbent insiders and the reduced recruitment of young outsiders are clearly affected by the nature of the downturn - whether it is temporary or prolonged - and by labour market institutions. For instance, these practices are more likely to be observed in countries where the employment protection of incumbents is stronger, and less likely when regulation is limited, as it was during the Great Depression. Other potentially relevant institutions that can impact on training incidence include labour unions, bargaining frameworks and product market regulation. There is evidence that some of these institutions affect training (see Bassanini et al., 2007, and the references therein), but no evidence that they affect the relationship between training and economic downturns.

Training policies are an important component of active labour market policies in the OECD countries and a potential tool to address the decline in the accumulation of human capital which could take place in a downturn. In spite of their diffusion, the empirical evidence on their efficacy is mixed: they often don't work, and if they work they do so in the medium term by affecting employment probabilities. Some commentators have concluded from this not that these policies should be abandoned, but that they should be accurately designed to improve their effects. Yet training policies are not the only tool available to foster the accumulation of human capital within firms: more structural policies, which affect product market regulation and labour market institutions, can also help.

\section{References}

Ariga, K. (2006). From golden eggs to rotten apples: Changes in the landscape of the market for new high school graduates in Japan. Kyoto University, Institute of Economic Research Working Paper.

Ariga, K., Brunello, G. \& Ohkusa Y. (2000). Internal labour markets in Japan. Cambridge: Cambridge University Press.

Askilden, J. \& Nilsen, O. (2005). Apprentices and young workers: A study of the Norwegian youth labour market. Scottish Journal of Political Economy, 52(1), 1-17.

Baker, G., Gibbs, M. \& Holmstrom, B. (1994). The wage policy of a firm. The Quarterly Journal of Economics, 109(4), 921-955.

Bassanini, A. \& Brunello, G. (2008). Barriers to entry and workplace training. IZA Discussion Paper No. 2746.

Bassanini, A., Booth, A., Brunello, G., De Paola, M. \& Leuven, E. (2007). Workplace training in Europe. In G. Brunello, P. Garibaldi and E. Wasmer (Eds.) Education and Training in Europe. Oxford: Oxford University Press.

Bilginsoy, C. (2003). The hazards of training: Attrition retention in construction industry apprenticeship programs. Industrial and Labor Relations Review, 57(1), 54-67.

Blanchard, O.J. \& Diamond, P. (1990). The Beveridge curve. NBER Working Paper No. R1405.

Boeri, T. \& Garibaldi, P. (2007). Two tier reforms of employment protection: a honeymoon effect?. The Economic Journal, 117(521), 357-385.

Brunello, G. \& Medio, A. (2001). An explanation of international differences in education and workplace training. European Economic Review, 45(2), 307-322.

Caballero, R.J. \& Hammour, M. L. (1994). The cleansing effect of recessions. American Economic Review, 84(5), 1350-1368.

Card, D., Kluve, J. \& Weber, A. (2009). Active labor market policy evaluations: A Meta-Analysis. IZA Discussion Paper No. 4002.

Croce, G. (2005). Limiti e prospettive della formazione continua in Italia. Economia e Lavoro, 2, 14-31. 
Culpepper, P. (1999). The future of the high skill equilibrium in Germany. Oxford Review of Economic Policy, 15(1), 43-59.

Dellas, H. \& Sakellaris, P. (2003). On the cyclicality of schooling: Theory and evidence. Oxford Economic Papers, 55, 148-72.

Elbaum, P. (1995). The economic rationale of apprenticeship training: Some lessons from British and US experience. Industrial Relations, 34(4), 593-622.

Felstead, A. \& Green, F. (1996). Training implications of regulation compliance and business cycles. In A. Booth \& D. Snower (Eds.) Acquiring Skills. Cambridge: Cambridge University Press.

Genda, Y. \& Kurosawa, M. (2001). Transition from school to work in Japan. Journal of the Japanese and International Economies, 15(4), 465-488.

Genda, Y. \& Rebick, M. (2001). Japanese labour in the 1990s: Stability and stagnation. Oxford Review of Economic Policy, 16(2), 85-102.

Genda, Y. (2005). A nagging sense of job insecurity: The new reality facing Japanese youth. Tokyo: International House of Japan.

Gielen, A. \& Van Ours, J. (2005). Age specific cyclical effects in job reallocation and labor mobility. IZA Discussion Paper 1670.

Greenhalgh, C. \& Mavrotas, R. (1993). Workforce training in the Thatcher era: Market forces and market failures. International Journal of Manpower, 14(2), 17-32.

Hall, R. (1991). Recessions as reorganizations. Stanford University Mimeo.

Harhoff, D. \& Kane, T. (1997). Is the German apprenticeship system a panacea for the US labour market?. Journal of Population Economics, 10, 171-196.

Hart, R. (2005). General human capital and employment adjustment in the Great Depression: Apprentices and journeymen in UK engineering. Oxford Economic Papers, 57, 169-189.

Heckman, J. J., Lalonde, R. J. \& Smith, J. A. (1999). The economics and econometrics of active labor market programs. In O. Ashenfelter \& D. Card (Eds.) Handbook of Labor Economics, edition 1, volume 3. Amsterdam: Elsevier.

Holmlund, B. \& Storrie, D. (2001). Temporary work in turbolent times: The Swedish experience. Uppsala University, Department of Economics Working Paper.

Holzer, H. (2009). Do Education and training belong in the recovery package?. Retrieved 2009 from http://www.urban.org/url.cfm?ID=901217.

Jaconebbinghaus, P., Mohrenweiser, J. \& Zwick, T. (2008). Wie kann die durchschnittliche Ausbildungsquote in Deutschland korrekt gemessen werden?. ZEW Discussion Paper 08-055.

Kahn, L. (2006). The long-term labor market consequences of graduating from college in a bad economy. Harvard University Working Paper.

Kato, T. (2000). The recent transformation of participating employment practices in Japan. NBER working paper No. 7965.

King, I. \& Sweetman, A. (2002). Procyclical skill retooling and equilibrium search. Review of Economic Dynamics, 5, 704-717.

Kluve, J. (2006). The effectiveness of European active labor market policy. IZA Discussion Paper No. 2018.

Kuczera, M., Brunello, G., Field, S. \& Hoffmann, N. (2008). Learning for jobs: Norway. Paris: OECD.

Lechner, M. \& Wunsch, C. (2006). Are training programs more effective when unemployment is high?. University of St.Gallen Working Paper.

Leuven, E. \& Oosterbeek, H. (2004). Evaluating the effect of tax deductions on training. Journal of Labor Economics, 22(1), 461-488.

Lindley, R. (1975). The demand for apprentice recruits by the engineering industry. Scottish Journal of Political Economy, 22, 1-24.

Majmudar, S. (2007). Market conditions and worker training: How does it affect and whom?. Labour Economics, 14, 1-23.

Martin, J. \& Grubb, D. (2001). What works and for whom: a review of OECD countries' experiences with active labour market policies. IFAU Working Paper No. 14

Messer, D. \& Wolter, S.C. (2009). Time-to-degree and the business cycle. Education Economics, forthcoming.

Muehlemann, S., Wolter, S.C. \& Wuest, A. (2009). Apprenticeship training and the business cycle. Empirical Research in Vocational Education and Training, 1(2), 177-190. 
Mühlemann, S., Schweri, J., Winkelmann, R. \& Wolter, S.C. (2007). An empirical analysis of the decision to train apprentices. LABOUR: Review of Labour Economics and Industrial Relations, 21(3), 419-441.

Natti, J., Aho, S. \& Halme, J. (2000) Does labour market training and subsidised employment reduce unemployment? An evaluation of the employment effects of labour market training and subsidised employment in Finland 1990-95. Prepared for the Nordic workshop on labour market research with register data, University of Tampere.

OECD (2009). Economic policy reforms 2009. Going for Growth. Paris: OECD

Oreopoulos, P., Von Watcher, T. \& Heisz, A. (2009). The short- and long-term career effects of graduating in a recession: Hysteresis and heterogeneity in the market for college graduates. IZA Discussion Paper No. 3578.

Rasmussen, A.R. \& Westergaard-Nielsen, N. (1999). The impact of subsidies on the number of new apprentices. Research in Labour Economics, 18, 359-375.

Ryan, P. (2000). The institutional requirements of apprenticeship: Evidence from smaller EU countries. International Journal of Training and Development, 4(1), 42-65.

Ryan, P. (2001). The school-to-work transition: a cross-national perspective. Journal of Economic Literature, 39, 34-92.

Ryan, P. (2009). Apprentice strikes, pay structure, and training in twentieth century UK metalworking industry. King's College Mimeo.

Saint-Paul, G. (1993). Productivity growth and the structure of the business cycle. European Economic Review, 37(4), 861-883.

Schweri, J. \& Mueller, B. (2008). Die Ausbildungsbereitschaft der Betriebe: Entwicklungen 1995 bis 2005. Neuenburg: Bundesamt für Statistik BFS.

Sepulveda, F. (2004). Training and business cycles. The Australian National University, Mimeo.

Sharpe, A., Arsenault, J. \& Laponte, S. (2008). Apprenticeship issues and challenges facing Canadian manufacturing industries. Ottawa: Centre for the Studies of Living Standards.

Stevens, M. (1994). An investment model for the supply of training by employers. The Economic Journal, 104(424), 556-570.

Toner, P. (2003). Supply side and demand side explanations of declining apprentice training rates: A critical overview. The Journal of Industrial Relations, 45(4), 457-484.

Wagner, K. (1998). The German apprenticeship system after unification. WZB Berlin Discussion Paper FS I 98 - 301. 
Table 1: Apprenticeship contracts in selected OECD countries

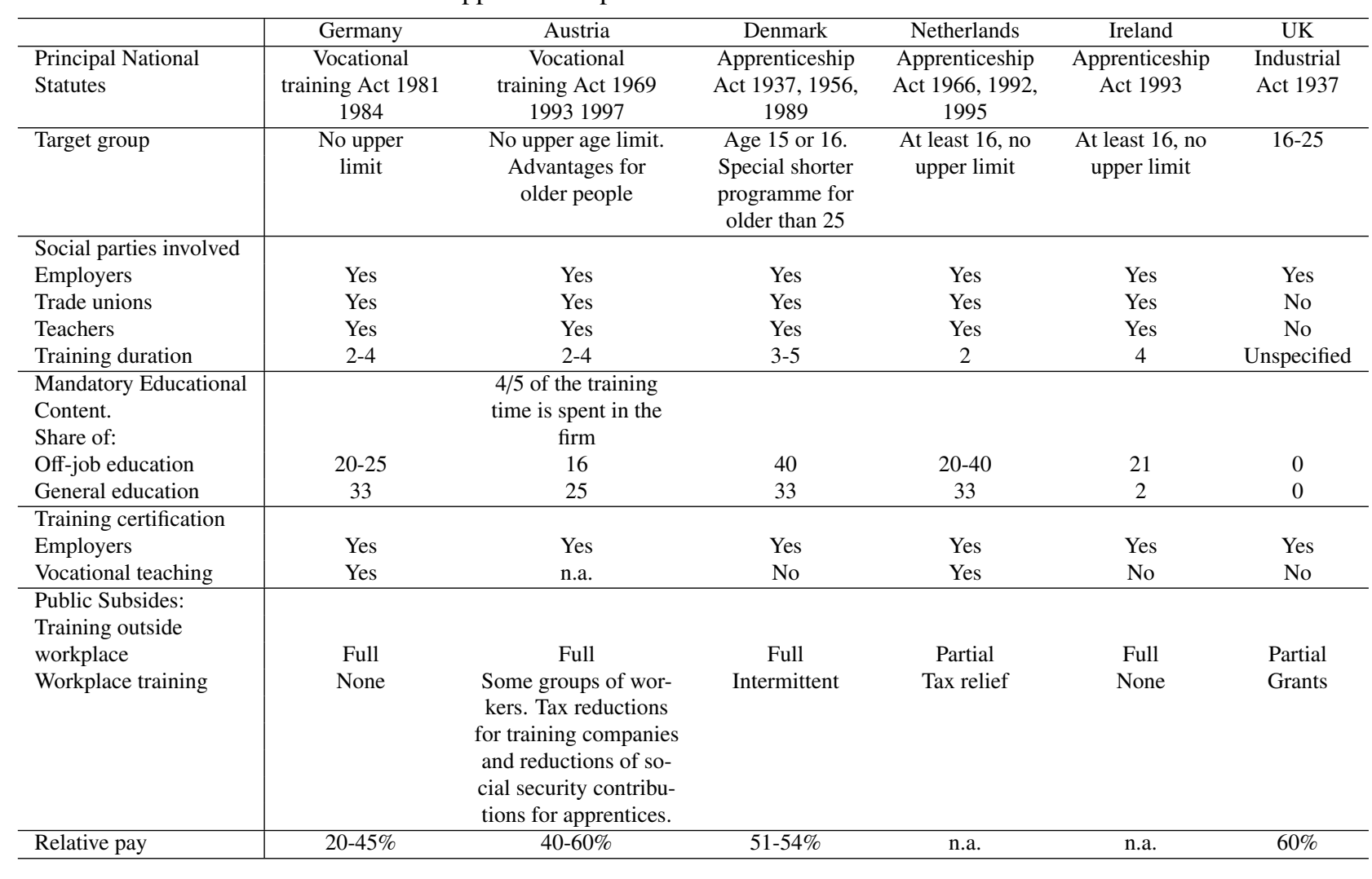


Table 1: Apprenticeship contracts in selected OECD countries, continued (1)

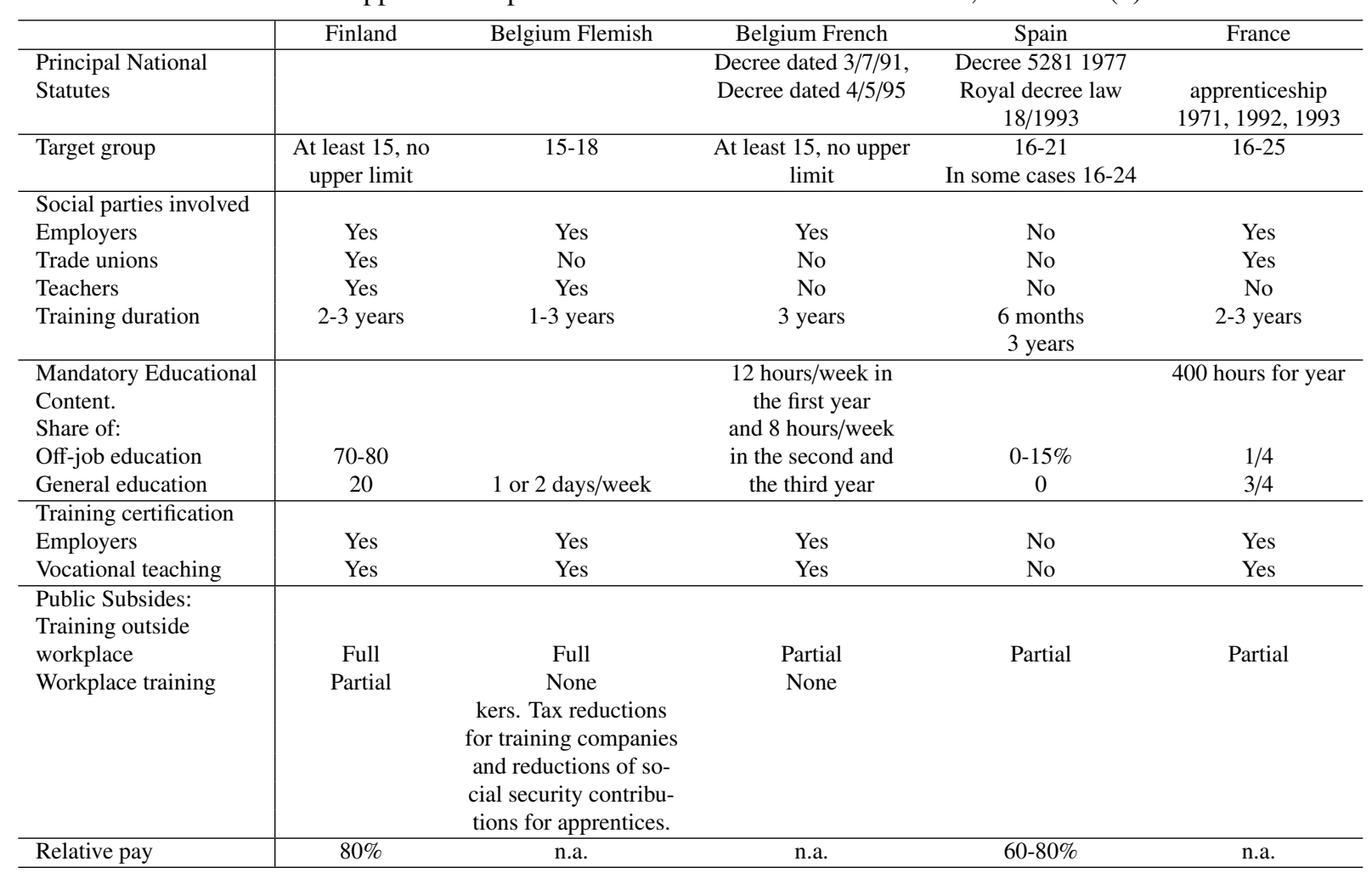


Table 1: Apprenticeship contracts in selected OECD countries, continued (2)

\begin{tabular}{|c|c|c|}
\hline & Italy & Switzerland \\
\hline $\begin{array}{l}\text { Principal National } \\
\text { Statutes }\end{array}$ & $\begin{array}{c}\text { Law N.25/1955 } \\
\text { and N. 6/1987, } \\
\text { Decree n. 276, } 2003\end{array}$ & $\begin{array}{l}\text { Vocational Education } \\
\text { and Training Act } 2002\end{array}$ \\
\hline Target group & $15-24$ & $\begin{array}{c}\text { Compulsory school } \\
\text { leavers, no upper age } \\
\text { limit }\end{array}$ \\
\hline $\begin{array}{l}\text { Social parties involved } \\
\text { Employers } \\
\text { Trade unions } \\
\text { Teachers } \\
\text { Training duration }\end{array}$ & $\begin{array}{c}\text { Yes } \\
\text { Yes } \\
\text { No } \\
\text { 2-6 years }\end{array}$ & $\begin{array}{c}\text { Yes } \\
\text { Yes } \\
\text { Yes } \\
\text { 2-4 years }\end{array}$ \\
\hline $\begin{array}{l}\text { Mandatory Educational } \\
\text { Content. } \\
\text { Share of: } \\
\text { Off-job education } \\
\text { General education }\end{array}$ & $\begin{array}{l}120 \text { hours of } \\
\text { formal training both } \\
\text { inside and outside } \\
\text { the firm }\end{array}$ & $\begin{array}{c}20-40 \% \\
10 \%\end{array}$ \\
\hline $\begin{array}{l}\text { Training certification } \\
\text { Employers } \\
\text { Vocational teaching }\end{array}$ & To be defined & $\begin{array}{l}\text { Yes } \\
\text { Yes }\end{array}$ \\
\hline $\begin{array}{l}\text { Public Subsides: } \\
\text { Training outside } \\
\text { workplace } \\
\text { Workplace training }\end{array}$ & $\begin{array}{c}\text { Tax relief } \\
\text { Tax relief, reductions } \\
\text { of social security } \\
\text { fcontributions for } \\
\text { apprentices }\end{array}$ & $\begin{array}{l}\text { Full } \\
\text { None }\end{array}$ \\
\hline Relative pay & n.a. & $10-36 \%$ \\
\hline
\end{tabular}

Sources: Bassanini et al. (2005), Ryan (2001) and Stefan Wolter and Adrian Wüest for Switzerland; n.a.: not available 
Table 2: The Cyclical Behaviour of Apprenticeships

\begin{tabular}{|c|c|c|c|c|}
\hline Study and Country & Data & Dependent Variable & Explanatory Variable & Qualitative results \\
\hline $\begin{array}{l}\text { Askilden and Nielsen } \\
\text { (2005), Norway }\end{array}$ & $\begin{array}{l}\text { Quarterly 1990-1996 } \\
\text { Firm level }\end{array}$ & $\begin{array}{l}\text { Cost shares - apprentices } \\
\text { of any age and workers } \\
\text { older than } 18 \text { (adults) }\end{array}$ & $\begin{array}{l}\text { Current unemployment } \\
\text { rate } u_{i} \text {, Forward un- } \\
\text { employment rate ( } 4 \text { quar- } \\
\text { ters) } u_{t+4}\end{array}$ & $\begin{array}{l}\text { Training pro-cyclical } \\
\text { Training ration pro- } \\
\text { cyclical }\end{array}$ \\
\hline $\begin{array}{l}\text { Steven (1994), } \\
\text { United Kingdom }\end{array}$ & $\begin{array}{l}\text { Engineering industry } \\
1967-1988\end{array}$ & $\begin{array}{l}\text { Log(apprentices/craft } \\
\text { employment) }\end{array}$ & $\begin{array}{l}\text { CBI capacity shortag } \\
\text { CAPSH, CBI skill shor- } \\
\text { tage SKSH }\end{array}$ & $\begin{array}{l}\text { Training ration pro- } \\
\text { cyclical }\end{array}$ \\
\hline $\begin{array}{l}\text { Felstead and Green } \\
\text { (1996), United } \\
\text { Kingdom }\end{array}$ & $\begin{array}{l}\text { Labour Force Survey- } \\
\text { recession early } 1990 \text { s }\end{array}$ & $\begin{array}{l}\text { Percentage doing appren- } \\
\text { ticeship, Percentage re- } \\
\text { ceiving job related } \\
\text { training }\end{array}$ & & $\begin{array}{l}\text { Training incidence mildly } \\
\text { pro-cyclical } \\
\text { Mild decline of appren } \\
\text { ticeships in the downturn }\end{array}$ \\
\hline $\begin{array}{l}\text { Hart (2005), United } \\
\text { Kingdom }\end{array}$ & Engineering Industry & $\begin{array}{l}\text { log apprentices } \\
\text { log journeymen }\end{array}$ & $\begin{array}{l}\text { Change in current un- } \\
\text { employment rate } \Delta u_{t} \\
\text { Chang in current un- } \\
\text { employment rate } \Delta u_{t-1}\end{array}$ & $\begin{array}{l}\text { Training pro-cyclical } \\
\text { Training ratio counter- } \\
\text { cyclical }\end{array}$ \\
\hline $\begin{array}{l}\text { Rasmussen and } \\
\text { Westergaar-Nielsen } \\
\text { (1999), Denmark }\end{array}$ & $\begin{array}{l}720 \text { plants with } \\
\text { apprentices 1980-1991 }\end{array}$ & $\begin{array}{l}\text { Probability of having a } \\
\text { new apprentice }\end{array}$ & $\begin{array}{l}\text { Ratio of new hires } \\
\text { ENTRY, Ratio of } \\
\text { leavers EXIT }\end{array}$ & $\begin{array}{l}\text { Probability of training } \\
\text { pro-cyclical }\end{array}$ \\
\hline $\begin{array}{l}\text { Schweri and Müller, } \\
\text { 2008, Switzerland }\end{array}$ & $\begin{array}{l}\text { Firm data 1995, 1998, } \\
2001,2005\end{array}$ & $\begin{array}{l}\% \text { of training firms } \\
\% \text { of young (age } 16) \text { who } \\
\text { start an apprenticeship }\end{array}$ & $\begin{array}{l}\text { Average GDP growth } \\
\text { in the past } 3 \text { years }\end{array}$ & $\begin{array}{l}\% \text { of training firms posi- } \\
\text { tively correlated with GDP, } \\
\% \text { of young (age } 16 \text { ) who start } \\
\text { an apprenticeship pro-cyclical }\end{array}$ \\
\hline
\end{tabular}


Table 2: The Cyclical Behaviour of Apprenticeships, continued

\begin{tabular}{|c|c|c|c|c|}
\hline Study and Country & Data & Dependent Variable & Explanatory Variable & Qualitative results \\
\hline $\begin{array}{l}\text { Wagner, 1998, } \\
\text { Germany }\end{array}$ & $\begin{array}{l}1990 \text { and } 1995 \text { (includes } \\
\text { the German recession of } \\
\text { early 1990s) }\end{array}$ & $\begin{array}{l}\text { Apprentices to employees } \\
\% \text { of firms doing training }\end{array}$ & & $\begin{array}{l}\text { Both are lower in } 1995 \text { than } \\
\text { in } 1990\end{array}$ \\
\hline \multirow[t]{2}{*}{$\begin{array}{l}\text { Bilginsoy (2003), } \\
\text { United States }\end{array}$} & Apprenticeship & \multirow{2}{*}{$\begin{array}{l}\text { Cancellation of a program } \\
\text { hazard, Completion of a } \\
\text { program hazard }\end{array}$} & \multirow[t]{2}{*}{ Unemployment rate $u_{t}$} & Cancelations pro-cyclical \\
\hline & $\begin{array}{l}\text { Information Management } \\
\text { Systems, 1995; } \\
\text { construction industry }\end{array}$ & & & $\begin{array}{l}\text { Cempletions pro cyclical } \\
\text { Apprenticeship duration } \\
\text { counter-cyclical }\end{array}$ \\
\hline $\begin{array}{l}\text { Mühlemann, Wolter } \\
\text { and Wüest (2009), } \\
\text { Switzerland }\end{array}$ & $\begin{array}{l}\text { Apprenticeship training } \\
\text { contract statistics, } 1988 \text { - } \\
2004\end{array}$ & $\begin{array}{l}\text { New apprenticeship training } \\
\text { contract at cantonal level }\end{array}$ & $\begin{array}{l}\text { Cantonal unemployment } \\
\text { rate }\end{array}$ & $\begin{array}{l}\text { New contracts } \\
\text { pro-cyclical }\end{array}$ \\
\hline
\end{tabular}


Table 3: The Cyclical Behaviour of training and schooling

\begin{tabular}{|c|c|c|c|c|}
\hline Study and Country & Data & Dependent Variable & Explanatory Variable & Qualitative results \\
\hline $\begin{array}{l}\text { Majundar (2007), } \\
\text { United States }\end{array}$ & $\begin{array}{l}\text { National Longitudinal } \\
\text { Survey of Youth 1988-96 } \\
\text { Workers who have joined } \\
\text { the firm since last wave }\end{array}$ & $\begin{array}{l}\text { Probability of receiving } \\
\text { company training }\end{array}$ & Local unemployment rate & $\begin{array}{l}\text { Probability } \\
\text { pro-cyclical }\end{array}$ \\
\hline $\begin{array}{l}\text { Sepulveda (2004), } \\
\text { United States }\end{array}$ & $\begin{array}{l}\text { National Longitudinal } \\
\text { Survey of Youth 1979-98 } \\
\text { quarterly }\end{array}$ & $\begin{array}{l}\text { Hours spent in OJT } \\
\text { HOurs spent in OFFJT } \\
\text { Training aincidence }\end{array}$ & Quarterly GDP & $\begin{array}{l}\text { Training and training } \\
\text { incidence counter- } \\
\text { cyclical }\end{array}$ \\
\hline $\begin{array}{l}\text { Dellas and } \\
\text { Sakellaris (2003), } \\
\text { United States }\end{array}$ & $\begin{array}{l}\text { Current Population Survery } \\
\text { High school graduates aged } \\
22-28\end{array}$ & College enrolment & $\begin{array}{l}\text { GNP } \\
\text { Unemployment rate }\end{array}$ & $\begin{array}{l}\text { Enrolment } \\
\text { counter-cyclical }\end{array}$ \\
\hline $\begin{array}{l}\text { Bassanini and } \\
\text { Brunello (2008), } \\
\text { Europe }\end{array}$ & $\begin{array}{l}\text { European Labour Force } \\
\text { Survey; employees aged } 25 \\
\text { to } 54\end{array}$ & Training incidence & $\begin{array}{l}\text { Log worked hours filtered } \\
\text { with the HP filter }\end{array}$ & $\begin{array}{l}\text { Trianing incidence } \\
\text { counter-cyclical }\end{array}$ \\
\hline $\begin{array}{l}\text { Messer and Wolter } \\
\text { (2009), Switzerland }\end{array}$ & $\begin{array}{l}\text { University graduate sur- } \\
\text { veys, 1981-2001 }\end{array}$ & Time-to-degree & Unemployment rate & $\begin{array}{l}\text { Number of semesters } \\
\text { pro-cyclical }\end{array}$ \\
\hline
\end{tabular}

